\title{
Bionic Eye and Retinitis Pigmentosa
}

\author{
Jan Lestak*, Martin Kyncl and Jaroslav Tintera \\ Ophthalmology clinic Faculty of Biomedical Engineering CTU in Prague, Czech Republic
}

*Corresponding author: Jan Lestak, Ophthalmology clinic Faculty of Biomedical Engineering CTU in Prague, Czech Republic

\begin{tabular}{|c|c|}
\hline ARTICLE INFO & ABSTRACT \\
\hline Received: 幽 July 01, 2019 & Citation: Jan Lestak, Martin Kyncl, Jaroslav Tintera. Bionic Eye and Retinitis Pigmentosa. \\
\hline Published: 慧 July 09, 2019 & Biomed J Sci \& Tech Res 19(3)-2019. BJSTR. MS.ID.003305. \\
\hline
\end{tabular}

\section{Introduction}

According to Fernandez et al. [1] approximately 140,000 blind people in the industrial countries could benefit from visual neuroprosthesis [1]. In the last quarter of a century, attention has been paid to retinal neuroprostheses with active stimulation (with external source of energy). Retinal neuroprostheses are structurally very similar. It is a small camera system placed in glasses that transmits the captured information to a video chip. This video chip translates them into electrical voltage changes and transmits them to a retinal implant consisting of a certain number of electrodes to stimulate retinal cells. Photodiodes built into the microchip can also be used instead of the camera. Even those require an external source of energy. The microchip with the electrodes can be implanted epiretinally, subretinally or suprachorioideally [24]. Similarly, the axons of these cells can also be stimulated with electrodes located in the sheath around the optic nerve Another level is the lateral geniculate body which can be stimulated by deep electrodes or more recently by a cluster of microelectrodes [5]. Similarly, also the visual cortex using the surface or deep electrodes according to Philip et al. [6].

\section{Retinitis Pigmentosa (RP)}

As the bionic eye is most commonly indicated in the patients with RP we will focus mainly on this diagnostic group. A prerequisite for the effectiveness of this system is a preservation of integrity of the middle and inner retinal structures, the visual pathway and the subcortical and cortical brain centers [7]. RP is a disease that primarily affects rods and cones and underlying retinal pigment epithelium. The inner core and plexiform layer, ganglion cells and their fibers undergo degeneration and are replaced by gliotic tissue. These changes are variable and can be visible at a later stage of the disease [8]. Our long experience in electrophysiology of vision show that already at the early phases of the diseases the rods but also the macular retinal structures including ganglion cells are altered. As a result, the optic nerve and the visual cortex are also damaged. We selected two patients with RP for this study. Both had similar subjective visual functions but a different age. The first patient was a male aged 38 years with RP within the Usher's syndrome. VARE: 0.5 naturally, VA-LE: 0.3 naturally. However, correction did not improve the sight. The perimetric examination showed a concentric narrowing of the visual fields to ten and five degrees in the right and left, respectively. Functional magnetic resonance imaging (fMRI) showed a significant decrease of activity, more following stimulation of the left eye (Figure 1). According to our methodology, the mean values of fMRI in the healthy population (for the corresponding age group) following monocular stimulation were: $9.200 \pm 2.700$ activated voxels [9]. The second patient was also a male of a higher age (63 years) with the VA-RE: 0.2, VA-LE: 0.3, naturally. However, correction did not improve the sight. The perimetric examination showed a concentric narrowing of the visual fields to ten and five degrees in the right and left, respectively. Electrophysiological examination showed a missing response bilaterally. Both in ERG, PERG and PVEP. Even with the above-mentioned visual functions, fMRI did not show any brain activity in the second patient after stimulation of each eye separately [10].

\section{Conclusion}

In both our patients with RP with relatively similar subjective (visual acuity, visual field) and relatively good visual functions, we showed a different depth of damage (fMRI) that is associated with the patient's age. These results show that the using of a bionic eye in advanced conditions of visual impairment and blindness cannot be expected to recover visual functions. Therefore, the trend should be focused some other way. 


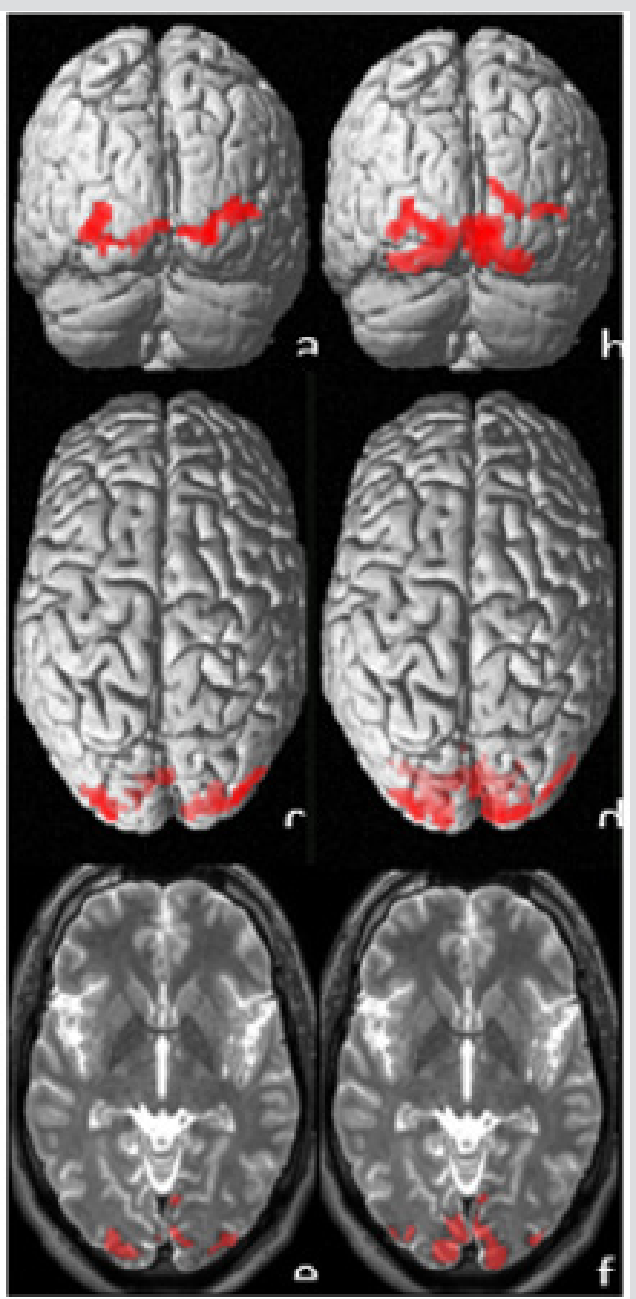

Figure 1: The activation after visual stimulation of the left (a, c, e) and right (b, d, f) eye. Upper line shows coronal $3 \mathrm{D}$ view $(\mathrm{a}, \mathrm{b})$, middle axial $3 \mathrm{D}$ view $(\mathrm{c}, \mathrm{d})$ and lower line shows selected 2D slices with activation projected over patients $\mathrm{T} 2 \mathrm{~W}$ scans. The entire number of statistically significant voxels of activation was 290 in case of left eye stimulation and 950 for right eye stimulation (threshold of $\mathrm{p}=0.05$ with FWE correction was used).

\section{ISSN: 2574-1241}

DOI: 10.26717/BJSTR.2019.19.003305

Jan Lestak. Biomed J Sci \& Tech Res

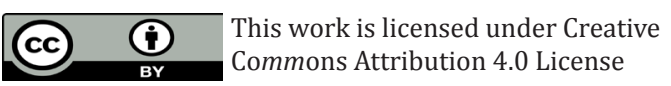

Submission Link: https://biomedres.us/submit-manuscript.php

\section{References}

1. Fernández E, Pelayo F, Romero S, Bongard M, Marin C, et al. (2005) Development of a cortical visual neuroprosthesis for the blind: the relevance of neuroplasticity. J Neural Eng 2(4): 1-12.

2. Fernandes RA, Diniz B, Ribeiro R, Humayun M (2012) Artificial vision through neuronal stimulation. Neuroscience Letters 519(2): 122-128.

3. Rizzo JF, Shire DB, Kelly SK, Troyk P, Gingerich M, et al. (2011) Development of the Boston retinal prosthesis. Conf Proc IEEE Eng Med Biol Soc 3135-3138.

4. Saunders AL, Williams CE, Heriot W, Briggs R, Yeoh J, et al. (2014) Development of a surgical procedure for implantation of a prototype suprachoroidal retinal prosthesis. Clin Exp Ophthalmol 42(7): 665-674.

5. Nguyen TN, Tangutooru SM, Rountree CM, Kantzos AJ, Tarlochan F, et al. (2016) Thalamic visual prosthesis. Transact Biomed Enginner 63(8): 1573-1850.

6. Lewis PM, Ackland HM, Lowery AJ, Rosenfeld JV (2015) Restoration of vision in blind individuals using bionic devices: A review with a focus on cortical visual prostheses. Brain Research 1595: 51-73.

7. Zrenner E, Bartz Schmidt KU, Benav H, Besch D, Anna Bruckmann, et al. (2011) Subretinal electronic chips allow blind patients to read letters and combine them to words. Proc R Soc B 278(1711): 1489-1497.

8. Bloome MA, Garcia ChA (1981) Manual of retinal and choroidal dystrophies. Appleton-Century- Crofts New York, 67(1): 71-72.

9. Kyncl M, Lestak J, Tintera J, Haninec P (2019) Traumatic optic neuropathy-a contralateral finding (case report). Experimental and Therapeutic Medicine 17(5): 4244-4248.

10. Lestak J, Zahlava J, Tintera J, Jiraskova N, Navratil L (2016) FMRI in a patient with pigmentary retinal dystrophy. Case report. Wulfenia Journal 23: 338-346.

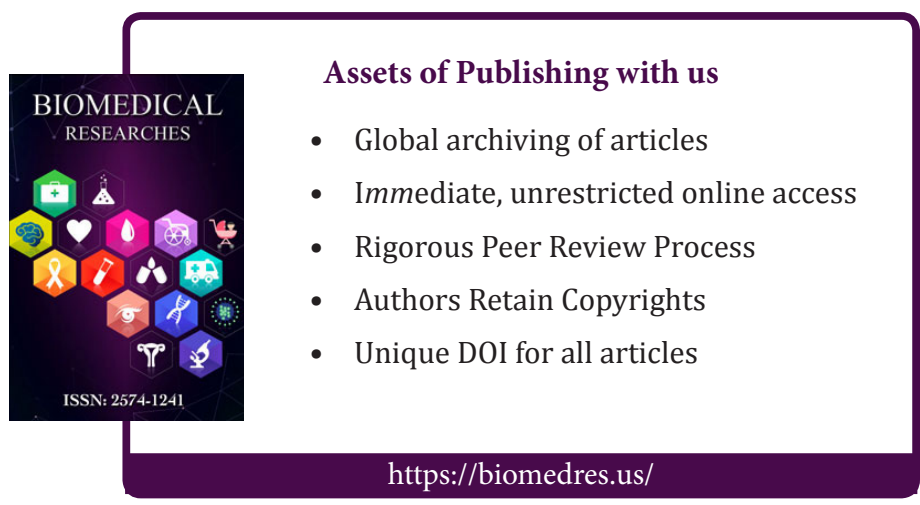

